Volume 13 Number 4, October-December 2019: pp. 345-360. Copyright (C) 2019 FIAT JUSTISIA. Faculty of Law, Lampung University, Bandarlampung, Lampung, Indonesia. ISSN: 1978-5186 | e-ISSN:2477-6238. Open Access: http://jurnal.fh.unila.ac.id/index.php/fiat

Fiat Justisia is licensed under a Creative Commons Attribution 4.0 International License, which permits unrestricted use, distribution, and reproduction in any medium, provided the original work is properly cited

\title{
Feminist Perspective towards the Legal Theory on Fisher-Women's Legal Entity
}

\author{
Rima Vien Permata Hartanto \\ Universitas Sebelas Maret, Indonesia \\ rimahartanto@yahoo.com \\ Adi Sulistiyono \\ Universitas Sebelas Maret, Indonesia \\ adi_sumo@yahoo.co.id \\ Isharyanto \\ Universitas Sebelas Maret, Indonesia \\ isharyanto_fh@staff.uns.ac.id
}

\begin{abstract}
This research explores the issue of the legal entity for fisher-women. Feminists Legal Theory is the main foundation. This theory seeks to criticise and dismantle the law by questioning the existence of laws that bring injustice to women's groups. In the Indonesian context, where the influence of patriarchal ideology and legal positivism theory is still active, the view that the law is believed to be neutral and objective has resulted in many things that discriminate and marginalise women's groups. This research presents the criticism of Law Number 7 of 2016 concerning the Protection and Empowerment of Fishermen, Fish Cultivators and Salt Cultivators for the recognition of the legal entity of fisher-women. This research is theoretical with the type of literature study focusing on ideas using a feminist perspective research approach. The results of the study indicates the that Law Number 7 of 2016 concerning the Protection and Empowerment of Fishermen, Fish Cultivators and Salt Farmers contains many weaknesses. There is a prejudice towards the work of fishers, there is a problem defining fishers because women are excluded from defining fishers, the absence of recognition of fisher-women affects the law and becomes indirect discrimination because of
\end{abstract}


gender blindness and does not take into account in terms of women's experience or interests.

Keywords: Feminist Legal Theory, Law Number 7 of 2016 concerning the Protection and Empowerment of Fishermen, Fish Cultivators and Salt Farmers, Fisher Woman Legal entity

How to Cite: Rima Vien Permata Hartanto, Adi Sulistiyono, Isharyanto,“ Feminist Perspective towards the Legal Theory on Fisher-Women's Legal Entity”, Fiat Justisia, 13 (4), (2019).

DOI: 10.25041/fiatjustisia.v13no4.1737

\section{A. Introduction}

The vast sea area owned by Indonesia and the potential of the resources within shows open employment opportunities in this sector, namely the profession as fishermen. The Law Number 7 of 2016 concerning the Protection and Empowerment of Fishermen, the Fish Cultivators and Salt Farmers is the legal standing for providing legal protection and social security to fishers in Indonesia. However, the implementation of this law does not favour small fishers, especially fisher-women. In reality, the socialanthropological aspect shows that fisher-women are actively involved in this occupation. ${ }^{1}$ Fisher-Women, have an essential role both in production work ${ }^{2}$, reproduction ${ }^{3}$ and social community. ${ }^{4}$ Unfortunately, the contribution of fisher-women in the fisheries production and non-production chains is often not recognised, because patriarchal society assumes that fishers are only men and fishing is an activity that is only done by men. ${ }^{5}$ Fishers are more often regarded as having male entities, so fisher-women as individuals in patriarchal

\footnotetext{
${ }^{1}$ Because fisher women are not recognized administratively, the work done by fisher women is not recorded in national statistics, particularly in the calculation of sectoral fisheries statistics. ${ }^{2}$ Hanna Papanek, "Family Status Production: The "Work" and "Non-Work" of Women", The Labor of Women: Work and Family, 4 (4), (1979), pp.775-781. Please see: Raidimi E. N, "The Roles and Activities of Women in The Six Selected Agricultural Projects in Thulamela Local Municipality of Vhembe District Municipality in the Limpopo Province", South African Journal of Agricultural Extension, 42 (2), (2014), pp.10-23.

${ }^{3}$ Rachapaetayakom J, "Changing Roles of Women: Reproduction to Production", Population Management, 2 (2), (1988), pp.18-27.

${ }^{4}$ V M Stenius, Veysey BM, Hamilton Z, Andersen R, "Social Roles in Women's Lives: Changing Conceptions of Self", The Journal of Behavioral Health Services \& Research, 32 (2), (2005), pp.182-198.

${ }^{5}$ Gayathri Lokuge and Dorothea Hilhorst, "Outside the Net: Intersectionality and Inequality in the Fisheries of Trincomalee, Sri Lanka”, Asian Journal of Women's Studies, 23 (4), (2017) pp. 473-497.
} 
culture are often considered not autonomous. ${ }^{6}$ Based on data from the Koalisi Rakyat untuk Keadilan Perikanan (KIARA) or People's Coalition for Fisheries Justice in 2015 shows that $48 \%$ of fishers families' income comes from women. However, the fact that women contribute $48 \%$ of family income is not recognised by the state. ${ }^{7}$

Based on the 1945 Constitution of the Republic of Indonesia in particular Article 27 paragraph (2), guarantees the equality for every citizen before the law. In Article 28D paragraph (1) of the 1945 Constitution of the Republic of Indonesia also regulates the right to recognition, guarantees, and protection and fair legal certainty; even so with Article 28I paragraph (1) of the 1945 Constitution of the Republic of Indonesia which regulates the right to be recognized as a person before the law. The Indonesian government has ratified CEDAW ${ }^{8}$ (Convention on Elimination of All Forms of Discrimination against Women) through The Law Number 7 of 1984 concerning Ratification of the Convention on Elimination of All Forms of Discrimination against Women which clearly states the state's obligation to attend to fulfil the fundamental rights of women. The Indonesian government has also stipulated Presidential Instruction Number 9 of 2000 concerning Gender Mainstreaming in Development which mandates that women's welfare must be included in every development policy. The Voluntary Guidelines for Securing Sustainable Small-Scale Fisheries in the Context of Food Securing and Poverty

${ }^{6}$ P. Aswathy and K. Kalpana, "The 'Stigma' of Paid Work: Capital, State, Patriarchy and Women Fish Workers in South India”, Journal of International Women's Studies, 19 (5), pp.113-128. Please see: Samuel, Lina, "Women, Work and Fishing: An Examination of the Lives of Fisherwomen in Kerala", South Asia Research, 27 (2), (2007), pp.205-227; Bindu Ramachandran, B, "Seafood Kitchen: Survival Strategy of Kerala's Fisherwomen in an Uncertain Economy”, International Journal of Rural Management, 13 (2), (2017), pp.199-205; dan S. Gunakara and Ramachandran Bhatta, "Socioeconomic Status of Fisher-Women in Segmented Fish Markets of Coastal Karnataka”, Agricultural Economics Research Review, 29 (2), (2016), pp.253-266.

${ }^{7}$ Pusat Data dan Informasi KIARA, (2015).

${ }^{8}$ The Convention on the Elimination of All Forms of Discrimination against Women (CEDAW) is an international treaty established in 1979 by the General Assembly of the United Nations. This agreement is considered a charter of international rights for women. Women's human rights in CEDAW are based on three principles: equality, non-discrimination and state obligations. Within these three principles lies the 'prism' of women's human rights. CEDAW also emphasizes equality and justice between women and men (equality and equity), namely equality of rights and opportunities, access and enjoyment of benefits in all areas of life and all activities. CEDAW is the most comprehensive convention on the protection and enforcement of women's rights because it provides details on the meaning of equality between women and men, and the steps needed to realize it. Furthermore, please see Achie Sudiarti Luhulima, "Convention on the Elimination of All Forms of Discrimination against Women (Women's Convention): Foundation, Principles, and Substance" in Achie Sudiarti Luhulima, Bahan Ajar Tentang Hak Perempuan: UU Nomor 7 Tahun 1984 Tentang Pengesahan Konvensi Penghapusan Segala Bentuk Diskriminasi terhadap Wanita, Jakarta: Yayasan Obor Indonesia, (2007), pp.134-135. 
Eradication-SSF Guidelines ${ }^{9}$ also stated explicitly the state's obligation to treat fisher-women including cultivators and salt farmers individually to obtain their fundamental rights. These guarantees include getting adequate housing, safe and hygienic basic sanitation, investment and credit savings, free from sexual harassment and violence, technological development, etc.

This study presents a critical analysis using the perspective of the Feminist Legal Theory (FLT) on Law Number 7 of 2016 concerning Protection and Empowerment of Fishermen, Fish Cultivators and Salt Farmers. For the sake of clarity, the research will be discussed consecutively; with the first glance about Feminist Legal Theory; secondly, criticism of Law Number 7 of 2016 concerning Protection and Empowerment of Fishermen, Fish Cultivators and Salt Farmers from the perspective of Feminist Legal Theory (FLT).

Therefore, the problem in this research is the regulation of Law Number 7 of 2016 concerning Protection and Empowerment of Fishermen, Fish Farmers and Salt Farmers regarding the existence of fisher-women concerning the Feminist Legal Theory.

\section{B. Research Methods}

This research is normative legal research combined with bibliographic research that focuses on ideas contained in theory. This research uses a feminist perspective research approach. ${ }^{10}$

\footnotetext{
${ }^{9}$ Voluntary Guidelines for Securing Sustainable Small-scale Fisheries in the Context of Food Security and Poverty Eradication is a Complementary Directive of the Code of Conduct for Responsible Fisheries (CCRF) adopted by the Food and Agriculture Organization (FAO) in 1995. After the adoption of the CCRF, there are various International Plan of Action (IPOA), including: IPOA on IUU Fishing, IPOA for the Management of Fishing Capacity and IPOA for the Conservation and Management of Sharks and various Technical Guidelines which are derivative instructions from the CCRF have been successfully ratified in various FAO sessions and adopted by its member countries, including Indonesia. Furthermore, after more than 1 (one) decade from the publication of the CCRF, one of the fundamental substances which is the CCRF's mandate related to the further regulation of small-scale fisheries can finally be agreed upon by FAO member countries. This is in the form of the ratification of this Voluntary Directive as an international guideline to guarantee sustainable small scale fisheries.

${ }^{10}$ According to Skiner et.al the main features of the feminist methodology are as follows: 1) Raising the importance of women's experience; 2) Rejecting the differences between researchers and those studied to eliminate power relations that can be shown by researchers to those studied; 3) Allowing groups that are historically marginalized to voice their concerns, confusion, and desires. 4) Realizing that researchers carry certain biases; 5)Avoid orthodoxy in the selection of research methods; 6) Rejecting the "scientificity" of certain methods, on the contrary, it combines various unconventional sources. Furthermore, seeTina Skinner et.al (Ed.), Researching Gender Violence: Feminist Methodology in Action, Devon: Willan Publishing, (2005).
} 
Sadli and Porter ${ }^{11}$ reiterate the characteristics of feminist methodology as follows:

1. The partiality for women are intended as:

a. Showing partiality to women as "victims". This partiality was shown from choosing research topics that deliberately chose conceptual and practical problematic issues that are faced by women, formulating research problems, building a theoretical framework with all its methodological consequences.

b. The research objective is not solely "about women", but "for women". It means to produce recommendations for improving a lot of women. ${ }^{12}$

c. Research validation is associated with women's experience as an indicator of reality. It means women's experience is considered an essential part of the research.

2. Gender as a "tool of analysis."

a. Gender relations are seen as influential factors in determining women's perceptions and lives. The focus of research is the specific problem of women as a consequence of gender relations, and the orientation of the approach is non-positivistic.

b. Not prioritising objective facts, namely facts or knowledge that are determined by something outside of women; women's perspective research emphasises the factor of empathy.

c. The tendency to use qualitative methods, such as focus group discussions, in-depth interviews, participatory observation to understand experiences.

d. Not rigidly sticking to specific methods (qualitative or quantitative). Quantitative research is sometimes also needed to find the distribution and mapping of a problem, while qualitative research is used to understand (verstehen) in-depth about a subject matter that is studied.

Legal material as research material is taken from literature materials which become primary and secondary legal materials. The primary legal content in this study is Law Number 7 of 2016 concerning Protection and Empowerment of Fishermen, Fish Cultivators and Salt Farmers. Secondary legal material in this study consists of various laws and regulations, especially

\footnotetext{
${ }^{11}$ Saparinah Sadli and Marilyn Porter, Metodologi Penelitian Berperspektif Perempuan Dalam Riset Sosial, Women's Studies Study Program, Postgraduate University of Indonesia, Not published, (1999).

12 The principle regarding research for and not about women means that research must have relevance for the woman being studied. This principle can produce a social policy based on the results of research or a group action to improve living conditions. Research on women means that what is being researched is made an instrument by researchers, usually to achieve economic success for these researchers. See Bowles,G. and R. Duelli Klein, Theories of Women's Studies, London: Routledge and Keagan Paul, (1985), p.95.
} 
in the field of fisheries and marine affairs, and data obtained from library materials consisting of books and legal journals. Legal material assortment techniques in this research use documentary studies and literature studies. Data obtained from the results of this study were compiled and analysed qualitatively, then the data are described descriptively.

\section{Discussion}

\section{A Glimpse of Feminist Legal Theory}

Feminist Legal Theory or Feminist Jurisprudence first appeared around the 1970s along with the development of the Critical Legal Study (CLS) ${ }^{13}$, as a school of thought that seeks to make inroads into the meaning and enactment of laws on women. Feminist Legal Theory breaks inequality caused by the mainstream view of law that an ideal law is neutral or objective.

According to Dennys Lloyd quoted by Donny Danardono, the concept of neutrality or objectivity of this law originates from the flow of Legal Positivism. ${ }^{14}$ However, the assumption that an ideal law is a neutral or objective law for feminists (defenders of women's human rights) legitimizes

\footnotetext{
13 The originators of the Critical Legal Study (CLS) are Karl Klare, Dunkan Kennedy, Mark Tushnet, Mark Kelman, Morton Horwitz, Jack Balkin and Roberto M. Unger. Although the scientific ideologies of these legal figures are diverse, they are united by the view that law cannot be separated from politics. See Dennis Lloyd, The Idea of Law. Middlesex: Penguin Books, (1973), pp. 213-217. CLS rejects the notion of neutral, objective and autonomous law. According to Roberto M. Unger, each particular legal method will produce certain legal choices; each law-making system also reflects certain socio-political values. Unger also said that law is inseparable from politics and various other non-legal norms, because law is formed by various non-legal factors such as economic, gender, race, or political interests. The formation of law also presupposes interaction and negotiation between various groups of people so that doctrinal legal analysis that isolates the law from its socio-political context results in the law not being able to overcome socio-political problems. The CLS then accommodates various schools of law opposing legal formalism or legal positivism, one of which is feminist legal theory. In other words, CLS is a generic name for legal realism, Marxist legal theory, feminist legal theory, postmodern legal theory. See Nicholas, K. Blomley. Law, Space, and the Geographies of Power. New York: The Guilford Press, p.11. Deborah L. Rodhe (1990) states that what distinguishes FLT from CLS is its focus on gender equality and the belief that this cannot be achieved with ideological structure institution. Furthermore, Rhode explained that, there were 3 (three) central commitments from feminists, including: (1) at the political level, seeking equality between men and women; (2) at the substantive level, raising the issue of gender as the focus of analysis by reformulating the practice of law that has been putting aside, not respecting and underestimating the interests of women; (3) at a methodological level, preparing a framework that takes into account women's experiences to identify social transformation for the achievement of gender equality. Furthermore, see Deborah, L. Rhode, Feminist Critical Theories. Stanford Law Review, (42), (1990), pp.617-619.

14 Donny Danardono, Teori Hukum Feminis: Menolak Netralitas Hukum, Merayakan Difference dan Anti Esensialisme. Perempuandan Hukum, Menuju Hukum yang Berperspektif Kesetaraan dan Keadilan, Jakarta: Convention Watch-Yayasan Obor, (2006), p.4.
} 
gender, ethnicity, race, and class inequality in society. For feminists, law which is considered neutral and objective by the theory of Legal Positivism ${ }^{15}$ is too good to be true, because these laws are made in a patriarchal perspective that protects men more than women. Feminists consider that good law is law that is in favour of women and anyone who is socially weakened.

Feminist Legal Theory holds that the law "male sex" as the law and legal theory are the domain of men because men dominate lawmakers, so the law and its effects are a reflection of masculine values. Therefore, the study of law according to Feminist Legal Theory must be based on women's experience so that women's experience becomes an essential focus in Feminist Legal Theory. Thus, this school of thought positions itself "impartially" to women to break the establishment of the law which is considered objective and neutral but instead results in discrimination and injustice to women.

Feminist Legal Theory cannot be separated from various feminist schools. ${ }^{16}$ In general, this theory is a picture of feminist theory in law that gave rise to a typical feminist analysis method in law to analyze very broad problems in various fields of law. The study, among others, criticises the law from the feminist point of view as one of its main studies. Because Feminist Legal Theory cannot be separated from the various schools, there is no uniformity of method. However, there are at least 5 (five) essential things

\footnotetext{
${ }^{15}$ Legal positivism is an inseparable part of the influence of the development of positivism (science), which views law as abstract, it must be concrete. This concretization is demonstrated by the necessity that the law must be written. Hart stated that the essence of legal positivism includes: 1) law is an order; 2) there is no need to link the law with the morality of the law as enacted, stipulated, positum, must always be separated from the law that should have been created, desired; 3 ) analysis or study of the meaning of legal concepts is an important study, the analysis or study must be distinguished from historical studies, sociological studies and critical judgments in moral meaning, social goals, and social functions; 4) the legal system is a logical closed system which is the right decisions that can be deducted logically from pre-existing rules; 5) moral punishment can no longer be upheld, but must be by way of rational argument or proof by means of evidence. Therefore, it can be said that the basic principles of legal positivism are 1) a state legal system applies not because it has a basis in social life (according to Comte and Spenser), nor because it originates in the soul of the nation (according to Savigny), and also not because of the basics of natural law, but because it gets its positive form in the authorized agency; 2) the law must be seen solely in its formal form; formal legal forms are separated from the material legal forms; and 3) the content of law (material) is acknowledged to exist but is not legal science material because it can damage the scientific truth of Law Science. See Achmad Ali, Menguak Tabir Hukum, Jakarta: Ghalia Indonesia, Second Edition, (2008), p.203 and Lili Rasjidi and I.B. Wyasa Putra, Hukum Sebagai Suatu Sistem, Bandung: Remaja Rosda Karya, (1993), p.81.

16 The diversity of feminist thought in general is divided into four major or main streams, namely Liberal Feminism, Radical Feminism, Cultural Feminism and Postmodern Feminsim. However, in addition to these large groups, there are several other schools, for example Psychoanalysis Feminism, Multicultural Feminism, Ecofeminism, etc.
} 
from the diversity of this theory which is called "think like feminist", namely the experience of women, the existence of implicit gender unfairness, double bondage and the dilemma of differences, the reproduction of male domination models, and opening women's choices. ${ }^{17}$

Apart from the five ways of thinking above, Katherine T. Bartlett also introduced a study method for Feminist Legal Theory. According to Bartlett, when feminists "do law"; as lawyers do in general, they also analyse the facts of existing legal problems, identify the essence of those facts, determine what legal principles can solve the problem and apply those principles to the events. In addition to the basic methods commonly practised by lawyers in general, feminists also use other methods, namely "asking woman question", "feminist practical reasoning" and "consciousness-raising". ${ }^{18}$ Other feminist methods used to broaden perceptions are through increased understanding with the aim of individual and collective empowerment. ${ }^{19}$ The three methods above can be used simultaneously and continuously.

\section{Criticism of Law Number 7 the Year 2016 Regarding the Protection and Empowerment of Fishermen, Fish Cultivators and Salt Farmers}

In 2015, the House of Representatives (DPR) of Indonesia included the Draft Law (Bill/RUU) on the Protection and Empowerment of Fishermen in the National Legislation Program (Prolegnas). In its development, the name of this bill was changed to the Bill on Protection and Empowerment of Fishermen, Fish Cultivators, and Salt Farmers. After going through various discussions, finally, the law was passed and declared effective since April 14, 2016.

The lack of recognition of fisher-women is very apparent when seeing Law Number 7 of 2016 concerning Protection and Empowerment of Fishermen, Fish Cultivators and Salt Farmers. Law Number 7 of 2016 concerning the Protection and Empowerment of Fishermen, Fish Cultivators and Salt Farmers consists of 78 Articles. However, this law only mentioned the word "woman" once and only about the role of women in the fishing households as stipulated in Article 45, which states: “... The empowerment activities as referred to in Article 43 pay attention to the involvement and role of women in the Fisherman household, Fish Farmer household and Salt Farmer household."

The above provisions implicitly state that the role of fisher-women is only in the domestic sphere so that no further explanation is needed regarding the role of women fishermen in the fishing household to help the family economy. Citing data from Koalisi Rakyat untuk Keadilan Perikanan (KIARA) or

\footnotetext{
${ }^{17}$ Martha Chamallas, Introduction to FLT, United States: Aspen Publisher, (2003), p.4.

${ }^{18}$ Katharine T. Barlet, Feminist Legal Methods. FLT Foundation, D. Kelly Weisberg (Ed), Temple University Press, (1993), p.551.

${ }^{19}$ Ibid. p.556.
} 
People's Coalition for Fisheries Justice stated that $48 \%$ of Indonesian coastal families' economy is related to the role of fisher-women. ${ }^{20}$ Following Mazur's opinion, the Article has shown that there is a very clear division of labour between women and men. ${ }^{21}$ The division of sexual labour is the division of labour based on gender. ${ }^{22}$ It is only a construction of a hierarchy and patriarchy where the division of sexual work dichotomises that some work is only appropriate for men can only do women and others. ${ }^{23}$

In the context of coastal communities, fishermen are men and fishing is an activity that is only done by men, which there is an expression of, "women go to sea, seriously?". This expression comes as a form of wonders and condescending expression for women who go to sea. These stereotypes cause the division of labour between men and women differently, where men get a more profitable portion than women based because men are suitable to be paid as public workers while women are entitled as domestic workers who are not paid. ${ }^{24}$

The gender imbalance among fishers profession is also seen in Article 1 of Law Number 7 of 2016 concerning Protection and Empowerment of Fishermen, Fish Cultivators and Salt Farmers. Article 1 point 3 of this law states that: "A fisher is any person whose livelihood is fishing". This provision, according to the perspective of Feminist Legal Theory or Feminist Legal Theory (FLT), is still gender blind because it does not explicitly mention men and women. The word "everyone" in this law has the potential to exclude/consider women as legal subjects, ${ }^{25}$ so "fisherman" is a genderneutral term. ${ }^{26}$ It is because the patriarchal culture that is still very strong in Indonesia in particular, coastal communities, which considers that the existence of women can be represented and their identity is attached to their husbands. So that "everyone" will be translated in the practice of this law as

\footnotetext{
${ }^{20}$ Pusat Data dan Informasi KIARA. (2015).

${ }^{21}$ A.G Mazur, Theorizing Feminist Policy, Oxford: Oxford University Press, (2002), pp.30-31.

22 The term sexual division of labor is generally used more often than the division of gender work although what is meant is the second meaning which emphasizes the cultural social dimension rather than its biological dimension.

23 RatnaSaptari and Brigitte Holzner, Perempuan, KerjadanPerubahanSosial. Jakarta: Kalyanamitra, (2016), p.26.

${ }^{24}$ AriefBudiman, PembagianKerjaSecaraSeksual, Jakarta: Gramedia, (1981), pp.14-20.

${ }^{25}$ Legal subjects are supporters and persons with rights and obligations, who have legal authority and that authority is obtained from law.

${ }^{26}$ D. Kleiber D, Harris LM and Vincent AC, "Improving fisheries estimates by including women's catch in the Central Philippines, Canadian Journal of Fisheries Aquatic, 71, (2014), pp. 656-664. Also see Branch TA and D. Kleiber., "Should we call them fishers or fishermen?", Fish Fisheries, 1, (2015). The term 'gender-neutral' means that something is not associated with women or men. This can refer to various aspects such as concepts or language styles. However, what is often considered gender neutral, including in the legal field precisely reflects gender blindness in practice (failure to recognize gender specificity).
} 
male ansich. Moreover, the characteristics of the sea that have been identified with masculinity, often regard the sea as an area that is not possible to be women's management area. On the contrary, land is considered the realm of women. ${ }^{27}$

The lack of recognition of fisher-women as legal subjects in the provisions of Article 1 point 3 of Law Number 7 of 2016 concerning the Protection and Empowerment of Fishermen, Fish Cultivators, and Salt Farmers also shows the existence of unclear formulation. Whereas in legislation theory, there is a principle of clarity that must be followed, namely that each legislation must meet the technical requirements to prepare for the legislation, systematic, choice of words or terms, and legal language that is clear and easy to understand so as not to cause various kinds of interpretations in its implementation. ${ }^{28}$ Poor recognition toward fisher-women as legal subject causes risk of unprovided legal protection for fisherwomen. It keeps women from access to development programs, especially social security protection for fisherwomen in Indonesia. It also retains women from accessing mainstream development programs. Naila Kabeer criticised this type of development paradigm because women are not involved in the process of policymaking. Moreover, the policy issue is only focused on women's role in the family, a housewife. The male group in the community is the main target of this development model. They are portrayed as head of the family and productive agents, while women receive a welfare program exclusively for their gender roles in the household. ${ }^{29}$

It must also be remembered that as one of the countries that have ratified CEDAW (Convention on the Elimination of All Forms of Discrimination against Women) through Law Number 7 of 1984 concerning Ratification of the Convention on the Elimination of All Forms of Discrimination against Women, the Indonesian Government should continue to ensure the achievement of equality of outcomes. It is in line with the state obligations stipulated in Article 4 of CEDAW, that states are obliged to make regulations and take special temporary measures aimed at accelerating the de facto equality between men and women. Law Number 7 of 2016 concerning Protection and Empowerment of Fishermen, Fish Cultivators and Salt Farmers is an opportunity to achieve substantive equality between men and women in the fisheries and marine resources sector, but unfortunately this law only contains the principle of justice in terms of efficiency. The principle of substantive equality in CEDAW also requires a substantive/corrective approach that is not only focused on equal treatment before the law but also

\footnotetext{
${ }^{27}$ Kusnadi, PerempuanPesisir. Yogyakarta: LKiS Publisher, (2006), p.3.

${ }^{28}$ Law Number 12 of 2011 concerning Formation of Legislation, Article 5 item $\mathrm{f}$.

${ }^{29}$ Nailla Kabeer, Reversed Realities: Gender Hierarchies in Development Thought, New Delhi: Kali for Women and International Books, (1994), p.5.
} 
equality in terms of the real impact of the existence of applicable laws/ regulations. Substantive equality considers and focuses on injustice and discrimination experienced by women as a result of patriarchal culture.

Thus, Law Number 7 of 2016 concerning Protection and Empowerment of Fishermen, Fish Cultivators and Salt Farmers has a problem in defining fishers. The narrow definition that fishers are only limited to fishing is actually improper also in terms of the fishermen's economy because the fisherman's economy must be seen as an integral whole between fishing, post-harvest processing, marketing, and consumption. If fishermen's activities are understood to be merely fishing activities, the impact is that the derivative definition only shows men as objects of the regulations and women are discriminated against it because they are excluded in their description. Whereas in the fishery world, it is not only the capturing process that is important, but post-harvest processing and marketing are also crucial because one of the characteristics of fish resources is perishable. So, even though fishers can catch a lot of fish, if the post-harvest processing and sales are problematic, the fishermen will not get a lot of money. The key figures involved in post-harvest and marketing are women. It is this narrow definition of a fisherman that makes women excluded from the fisheries sector. ${ }^{30}$

Based on the description above, then Law Number 7 of 2016 concerning Protection and Empowerment of Fishermen, Fish Cultivators and Salt Farmers becomes an indirectly discriminatory regulation (indirect discrimination) ${ }^{31}$ because it is gender blind ${ }^{32}$, using men's standards and does not take into account aspects of women's experience or interests. The definition of fishers that does not mention men and women who have simplified (simplified or

${ }^{30}$ Dedi Adhuri, "Marginalisasi Perempuan Nelayan adalah Produk Kultur dan Kebijakan yang Diskriminatif", Jurnal Perempuan, 22 (4), (2017), pp.142-143.

31 According to Jawahir Thantowi, discrimination is the treatment given by the state / government to a number of people or communities unequally for the guarantee of basic rights and basic freedom of rights whether due to ethnicity, religion, race, and gender. Discrimination results in the inaccessibility of various basic needs for food, shelter, education, health, freedom of information, safety, and comfort appropriately by a group of people. See Jawahir Thantowi, Terorisme Negara: Kerjasama Konspiratif Menjinakkan Islam Fundamentalis, Yogyakarta: UII Press, (2013), p.176. Whereas Article 1 number 3 of Law Number 39 of 1999 Concerning Human Rights states that discrimination is any direct, indirect limitation, harassment or exclusion based on human distinctions on the basis of religion, ethnicity, race, ethnicity, group, class, status social, economic status, gender, language, political beliefs, resulting in the reduction, deviation or elimination of the recognition, implementation or use of human rights and basic freedoms in life both individually and collectively in the political, economic, legal, social, cultural, and other aspects of life. Discrimination does not occur immediately when regulations that appear to be neutral but become discriminatory when applied in the field.

${ }^{32}$ Gender blindness means ignoring the various roles, responsibilities, abilities, needs and priorities of women and men. Gender blind policies are based on information derived from men's activities and / or consider those affected by the policy to have the same needs and interests (men). 
even eliminated) the role of women fishermen is very detrimental so that it will strengthen discrimination and injustice against women which has been happening a lot.

\section{Conclusions}

Based on an analysis using the Feminist Legal Theory, in Law Number 7 of 2016 concerning Protection and Empowerment of Fishermen, Fish Cultivators and Salt Farmers, held several weaknesses, namely the existence of prejudice towards the work of fishers. There are also problems defining fishers because women are excluded from defining fishers, lacking recognition of fisher-women so that fisher-women are not considered as stakeholders and active subjects. Thus, Law Number 7 of 2016 concerning Protection and Empowerment of Fishermen, Fish Cultivators and Salt Farmers becomes a regulation that is indirectly discriminatory because of gender blindness and does not take into account aspects of experience or women's interests.

In accordance with the Feminist Legal Theory which believes that the existence and identity of women in law are not equal to men because in general women will always be attached to the private or domestic sphere even though this is not clearly written in the law, but women will still be considered as "the other" or "liyan" (Javanese) in the law because their identity is degraded by the control and sovereignty of their husbands/men. ${ }^{33}$ This fact shows that the state, through its laws has contributed to the subordination and marginalisation of fisher-women.

Therefore, the Government of Indonesia needs to amend Law Number 7 of 2016 concerning Protection and Empowerment of Fishermen, Fish Cultivators and Salt Farmers on several issues. First, fisher-women must be placed as stakeholders, that is, as active, autonomous subjects by paying attention to aspects of the experience and interests of fisher-women. Second, the need to redefine and expand the terms of fishers who must accommodate the work of women in the marine and fisheries sector, starting from pre and post-production fisheries, because it cannot be denied that the contribution of women in this sector is substantial both in the family, community and state economy. Third, refinement of the principle in Article 2 point (g) of Law Number 7 of 2016 concerning Protection and Empowerment of Fishermen, Fish Cultivators and Salt Farmers, namely "efficient-fairness" needs to be changed into "equality and fairness", and erase the word "efficiency" because the meaning has been contained in item (c), namely "usefulness".

33 H. A. Barnett, Introduction to feminist jurisprudence, London: Cavendish Publishing Limited, (1998), p.65. 


\section{A. Book}

\section{Bibliography}

Ali, A. (2008). Menguak Tabir Hukum. Jakarta: Ghalia Indonesia. Second Edition.

Barnett, H. A. (1998). Introduction to Feminist Jurisprudence. London: Cavendish Publishing Limited.

Bowles, G. and R. Duelli Klein. (1985). Theories of Women's Studies. London: Routledge and Keagan Paul.

Budiman, Arief. (1981). Pembagian Kerja Secara Seksual. Jakarta: Gramedia.

Chamallas, Martha. (2003). Introduction to FLT. United States: Aspen Publisher.

Connell, R. W. (2005). Masculinities. 2nd ed. Berkeley. Calif: University of California Press.

Danardono, D. (2006). Teori Hukum Feminis: Menolak Netralitas Hukum, Merayakan Difference dan Anti Esensialisme.Perempuandan Hukum, Menuju Hukum yang Berperspektif Kesetaraan dan Keadilan. Jakarta: Convention Watch- Yayasan Obor.

Dennis Lloyd. (1973). The Idea of Law. Middlesex: Penguin Books.

Ibrahim, J. (2006). Teori dan Metodologi Penelitian Hukum Normatif. Malang: Bayu Media Publishing.

Katharine T. Barlet. (1993). Feminist Legal Methods.FLT Foundation, D. Kelly Weisberg (ed). Temple University Press.

Kusnadi. (2006). Perempuan Pesisir. Yogyakarta: LkiS.

Lili Rasjididan I.B. Wyasa Putra. (1993). Hukum Sebagai Suatu Sistem. Bandung: Remaja RosdaKarya.

Luhulima, Achie Sudiarti. (2007). Bahan Ajar Tentang Hak Perempuan: UU Nomor 7 Tahun 1984 Tentang Pengesahan Konvensi Penghapusan Segala Bentuk Diskriminasi Terhadap Wanita. Jakarta: Yayasan Obor Indonesia.

Mazur, A.G. (2002). Theorizing Feminist Policy, Oxford: Oxford University Press.

Nicholas, K. Blomley. (2015). Law, Space, and the Geographies of Power. New York: The Guilford Press.Pusat Data dan Informasi KIARA.

Rhode, Deborah L. (2018). Feminist Critical Theories. UK: Stanford Law Review. https://doi.org/10.4324/9780429500480-19.

Sadli, Saparinah and Marilyn Porter.(1999). Metodologi Penelitian Berperspektif Perempuan Dalam Riset Sosial. Women's Studies Program, Postgraduate University of Indonesia. Not Published Saptari, Ratnadan Brigitte Holzner.(2016). Perempuan, Kerjadan Perubahan Sosial. Jakarta: Kalyanamitra. 
Skinner, Tina et.al (Ed.). (2005). Researching Gender Violence: Feminist Methodology in Action. Devon: Willan Publishing.

Thantowi, Jawahir. (2013). Terorisme Negara: Kerjasama Konspiratif Menjinakkan Islam Fundamentalis. Yogyakarta: UII Pres.

\section{B. Journal}

B. Bindu Ramachandran, "Seafood Kitchen: Survival Strategy of Kerala's Fisherwomen in an Uncertain Economy", International Journal of Rural Management, $13 \quad$ (2), (2017), pp.199-205 https://doi.org/10.1177/0973005217721005.

Branch T A and D. Kleiber, "Should We Call Them Fishers or Fishermen?", Fish Fisheries, 18 (1), (2017), https://doi.org/10.1111/faf.12130.

D. Kleiber D, Harris LM and Vincent AC, "Improving fisheries estimates by including women's catch in the Central Philippines", Canadian Journal of Fisheries Aquatic, 71 (5), (2014), pp. 656664, https://doi.org/10.1139/cjfas-2013-0177.

Dedi Adhuri, "Marginalisasi Perempuan Nelayan adalah Produk Kultur dan Kebijakan yang Diskriminatif”, Jurnal Perempuan, 22 (4), (2017), pp.142-143.

E. N. Raidimi, "The Roles and Activities of Women in The Six Selected Agricultural Projects in Thulamela Local Municipality of Vhembe District Municipality in the Limpopo Province", South African Journal of Agricultural Extension, 42 (2), (2014), pp.10-23.

Gayathri Lokuge and Dorothea Hilhorst, "Outside the Net: Intersectionality and Inequality in the Fisheries of Trincomalee, Sri Lanka", Asian Journal of Women's Studies, 23 (4), (2017), pp. 473-497, https://doi.org/10.1080/12259276-2017.1386839.

Gunakara S and Ramachandra Bhatta, "Socioeconomic Status of FisherWomen in Segmented Fish Markets of Coastal Karnataka", Agricultural Economics Research Review, 29 (2), (2016), pp.253-266, https://doi.org/10.5958/0974-0279.2016.00052.5.

Hanna Papanek, "Family Status Production: The "Work" and "Non-Work" of Women", The Labor of Women: Work and Family, 4 (4), (1979), pp.775-781, https://doi.org/10.1086/493663.

J. Rachapaetayakom, "Changing Roles of Women: Reproduction to Production", Population Management, 2 (2), (1988), pp.18-27.

P. Aswathy and K. Kalpana, "The 'Stigma' of Paid Work: Capital, State, Patriarchy and Women Fish Workers in South India", Journal of International Women's Studies, 19 (5), pp.113-128.

R. W. Connell, and James W. Messerschmidt, "Hegemonic Masculinity: Rethinking the Concept", Gender and Society, 19 (6), (2005), https://doi.org/10.1177/0891243205278639. 
S Coulthard and Britton E, "Waving or Drowning: An Exploration of Adaptive Strategies Amongst Fishing Households and Implications for Wellbeing Outcome", Sosiologia Ruralls, 55 (3), (2015), https://doi.org/10.1111/soru.12093.

Samuel, Lina, "Women, Work and Fishing: An Examination of the Lives of Fisherwomen in Kerala", South Asia Research, 27 (2), (2007), pp.205227, https://doi.org/10.1177/026272800702700205.

V. M Stenius, Veysey BM, Hamilton Z, Andersen R, "Social Roles in Women's Lives: Changing Conceptions of Self", The Journal of Behavioral Health Services \& Research, 32 (2), (2005), pp.182-198, https://doi.org/10.1097/00075484-200504000-00007.

\section{Legislation}

The 1945 Constitution of the Republic of Indonesia.

Law Number 7 on 1984 of Ratification of the Convention on the Elimination of All Forms of Discrimination Against Women.

Law Number 39 on 1999 of Human Rights.

Law Number 12 on 2011 of Formation of Regulations and Regulations

Law Number 7 on 2016 of Protection and Empowerment of Fishermen, Fish and Salt Farmers.

Presidential Instruction Number 9 on 2000 of Gender Mainstreaming in Development. 
